\title{
Suppression of Splanchnic Ketone Body Production in Man by Nicotinic Acid*
}

\author{
Lars A. Carlson, Ulla Freyschuss, Jan KJellberg and Jan Östiman
}

Departments of Internal Medicine, Clinical Physiology and Endocrinology and Metabolism, Karolinska Sjukhuset and King Gustaf Vth Research Institute, Stockholm, Sweden

Received June 2, 1967

Summary. The effect of nicotinic acid on splanchnic blood flow and splanchnic metabolism of free fatty acids and $\beta$-hydroxybutyric acid was studied in four normal subjects, two patients with diabetes and one patient with uncomplicated obesity. The main purpose of the study was to explore the mechanism behind the reduction in plasma levels of $\beta$-hydroxybutyric acid induced by nicotinic acid. - Plasma levels of free fatty acids and $\beta$ hydroxybutyric acid were promptly reduced by nicotinic acid. There was a positive correlation between the arterial concentration of free fatty acids and the arterial - hepatic vein difference of free fatty acids. From this apparently linear relationship it was calculated that at any arterial level of free fatty acids one quarter of the amount of free fatty acids delivered to the splanchnic region was taken up there. - The splanchnic production of $\beta$-hydroxybutyric acid was, on the average, reduced by 95 per cent 40 and 60 minutes after administration of nicotinic acid. It is suggested that reduced hepatic formation of $\beta$-hydroxybutyric acid is the main cause of the lowering of plasma levels of this ketone body after administration of nicotinic acid to man.

Suppression par l'acide nicotinique, de la production de corps cetonique dans le territoire splanchnique chez l'homme

Résumé. On a étudié l'effet de l'acide nicotinique sur le débit sanguin splanchnique et sur le métabolisme splanchnique des acides gras libres et de l'acide $\beta$-hydroxybutyrique, chez 4 sujets normaux, deux patients atteints de diabète et un patient atteint d'obésité sans complication. Le principal but de cette étude était $d^{\prime}$ explorer le mécanisme impliqué dans la réduction des taux plasmatiques d'acide $\beta$-hydroxybutyrique, provoquée par l'acide nicotinique. - Les taux plasmatiques des acides gras libres et de l'acide $\beta$-hydroxybutyrique étaient réduits rapidement par l'acide nicotinique. La différence entre la concentration artérielle des acides gras libres et leur concentration dans la veine hépatique était en corrélation positive avec la concentration artérielle de ces acides gras libres. A partir de cette relation apparemment linéaire, on a calculé qu'à n'importe quel taux artériel des acides gras libres, un quart de la quantité des acides gras libres arrivant dans la région splanchnique y était capté. - La production splanchnique d'acide $\beta$ hydroxybutyrique était réduite en moyenne de 95 pour cent, 40 et 60 minutes après l'administration d'acide nicotinique. On suggère que la formation hépatique réduite d'acide $\beta$-hydroxybutyrique est la cause principale de l'abaissement des taux plasmatiques de ce corps cétonique, après administration d'acide nicotinique à l'homme.

Verminderung der Ketonkörperprodultion im Splanchnicus-Gebiet durch Nicotinsäure bei Menschen

Zusammenfassung. Die Wirkung der Nicotinsäure auf den Blutdurchfiuß im Splanchnicus-Gebiet und den Stoffwechsel der freien Fettsäure und der $\beta$-Hydroxybuttersäure im Splanchnicus-Gebiet wurde bei 4 normalen Personen, zwei Diabetikern und einem Patienten mit unkomplizierter Fettsucht untersucht. Das Hauptanliegen dieser Arbeit war es, den Mechanismus zu erforschen, der die Reduktion des Plasmaspiegels von $\beta$-Hydroxybuttersäure durch Nicotinsäure bewirkt. - Die Plasmaspiegel der freien Fettsäuren und der $\beta$-Hydroxybuttersäure wurden durch Gabe von Nicotinsäure prompt herabgesetzt. Es ließ sich eine positive Korrelation zwischen der Konzentration der freien Fettsäuren in der Arterie und der Differenz der freien Fettsäuren zwischen Arterie und Lebervene feststellen. Aus dieser offensichtlich linearen Beziehung ließ sich berechnen, daß bei jedem arteriellen Spiegel der freien Fettsäuren jeweils ein Viertel der Menge der freien Fottsäuren, die in das Splanchnicus-Gebiet abgegeben wurden, dort aufgenommen wurden. - Die Produktion von $\beta$-Hydroxybuttersäure im SplanchnicusGebiet wurde im Mittel durch Gabe von Nicotinsäure um 95\% 40 und 60 Minuten nach der Gabe von Nicotinsäure reduziert. Man darf annehmen, daß die herabgesetze Bildung von $\beta$-Hydroxybuttersëure in der Leber die Hauptursache für die Erniedrigung der Plasmaspiegel dieses Ketonkörpers nach Gabe von Nicotinsäure bei Menschen ist.

Key-words: FFA, $\beta$-hydroxybutyric acid, nicotinic acid, diabetes, splanchnic production, splanchnic blood flow.
The phenomenon of ketosis and its clinical importance have been recognized for many years. The recent rapid development of our understanding of lipid metabolism has opened new approaches to the understanding and the treatment of ketosis. From various studies in man and animals a positive relationship has been found between the rate of mobilization of free fatty acids (FFA) from adipose tissue and the levels of ketone bodies in blood [cf. 6]. This led us to study the

* Supported by grants from Syskonen Wesséns stift. else and the Swedish Medical Research Council (19X204-03). effect of nicotinic acid on the concentration of $\beta$ hydroxybutyric acid ( $\beta$-HBA), the major ketone body in human plasma [8]. Nicotinic acid was used for this purpose because it effectively and promptly inhibits the mobilization of FFA from adipose tissue $[7,4,5]$. We were able to demonstrate that nicotinic acid in diabetic patients as well as in obese, non-diabetic subjects caused the usual prompt lowering of plasma FFA and that this effect was rapidly followed by a pronounced decrease in plasma concentration of $\beta$-HBA [8].

However, the mechanism for the rapid lowering of $\beta$-HBA could not be definitely established. The lowering might be due to decreased hepatic ketone 
body formation, caused by decreased availability of acetyl-CoA due to the decreased influx of FFA into the liver. It would, however, be equally possible that there was an increased peripheral utilization of ketone bodies when the level of a major substrate for respiration FFA - had been lowered [14, 17, 12]. From the therapeutic point of view it would be desireable if diabetic ketonemia could be decreased by lowering hepatic ketone body formation.

This study was designed to determine if the effect of nicotinic acid on plasma $\beta$-HBA was primarily due to an effect on hepatic formation of ketone bodies. Hepatic vein catheterization was performed and brachial artery-hepatic vein difference of $\beta$-HBA and FFA as well as hepatic plasma flow were determined. The study is part of an extensive study of splanchnic carbohydrate and lipid metabolism in man under various conditions.

\section{Material and Methods}

All subjects were studied in the morning after fasting overnight. Four of the subjects were healthy as judged from medical history and routine clinical examination. Two were newly discovered, insulindependent diabetics who had received no treatment, and the last had uncomplicated obesity. By percutaneous techniques one teflon eatheter was introduced into one brachial artery and another catheter into an antecubital vein and a primer of $6 \mathrm{mg}$ of Indiocyanine green (Cardio-Green, Hynson, Westcott \& Dunning, Ltd) was given i.v. followed by a constant infusion of the dye at a rate of about $0.5 \mathrm{mg} / \mathrm{min}$. The dye was dissolved in 0.9 per cent saline containing 2 per cent human serum albumin (Kabi, Stockholm). The solution was infused at a rate of about $0.5 \mathrm{ml} / \mathrm{min}$. The hepatic vein was then catheterized from a right arm samples, about $15 \mathrm{ml}$, were drawn simultaneously and at the same rate from the artery and the hepatic vein into heparinized syringes, the sampling generally taking 1-3 minutes. During the basal period, i.e. the period before nicotinic acid was given, which lasted for 30 to 75 minutes (about 60 minutes in most cases) repeated blood samples were taken as indicated in the figures. At the end of this period nicotinic acid was given intravenously as a $5 \%$ solution of the sodium salt. Two hundred $\mathrm{mg}$ was given four times as indicated in the figures. The first injection was given over $3-5$ minutes to minimize reactions due to the flush; subsequent injections were given more rapidly.

The blood samples were stored in ice water, and processed immediately after the study was completed. Indiocyanine green in plasma was determined by reading the optical densities of plasma at 800 and $620 \mathrm{~m} \mu$ [19]. The arterial level of the dye remained constant in most subjects and varied between 0.5 and $0.7 \mu \mathrm{g} / \mathrm{ml}$. Only in a few instances and then usually $5-10$ minutes after nicotinic acid were there significant changes in the arterial concentration of dye. In calculating plasma flow in these instances the volume of distribution of the dye was considered to be equal to the plasma volume. The plasma volume was determined with 131I-labelled albumin. Plasma FFA was determined according to Dole [9] with two washings of the heptane phase with sulphuric acid [16]. $\beta$-HBA was estimated enzymatically according to the procedure of Williamson, Mellanby and Krebs [18].

\section{Results}

Some data on the subjects in this study are included in Table 1. Weight and blood glucose values were within normal limits except for the obese and the two diabetic subjects, respectively.

Table 1. Summary of data on the subjects, obtained at the beginning of the study

\begin{tabular}{|c|c|c|c|c|c|c|c|c|c|}
\hline \multirow[b]{2}{*}{ No. } & \multirow[b]{2}{*}{ Diagnosis } & \multirow[b]{2}{*}{$\begin{array}{l}\text { Age } \\
\text { years }\end{array}$} & \multirow[b]{2}{*}{ Sex } & \multirow[b]{2}{*}{$\begin{array}{l}\text { Height } \\
\mathrm{cm}\end{array}$} & \multirow[b]{2}{*}{$\begin{array}{l}\text { Weight } \\
\mathrm{kg}\end{array}$} & \multirow[b]{2}{*}{$\begin{array}{l}\text { Blood } \\
\text { sugar } \\
\mathrm{mg} / 100 \mathrm{ml}\end{array}$} & \multicolumn{3}{|l|}{ Plasma } \\
\hline & & & & & & & $\begin{array}{l}\text { Choles- } \\
\text { terol } \\
\mathrm{mg} / 100 \mathrm{ml}\end{array}$ & $\begin{array}{l}\text { Phospho- } \\
\text { lipids } \\
\text { mg/100 } \mathrm{ml}\end{array}$ & $\begin{array}{l}\text { Trigly- } \\
\text { cerides } \\
\text { mmole/ } 1\end{array}$ \\
\hline 1 & Normal & 25 & $\mathbf{M}$ & 180 & 71 & 66 & 154 & 208 & 1.08 \\
\hline 2 & Normal & 22 & $\mathbf{M}$ & 188 & 73 & 71 & 154 & 186 & 0.52 \\
\hline 3 & Normal & 23 & $\mathbf{M}$ & 185 & 69 & 88 & 155 & 279 & 0.92 \\
\hline 4 & Normal & 27 & $\mathrm{M}$ & 178 & 78 & 83 & 143 & 228 & 0.59 \\
\hline 5 & Diabetes & 22 & $\mathrm{M}$ & 185 & 72 & 215 & 226 & 239 & 2.19 \\
\hline 6 & Diabetes & 22 & $\mathrm{M}$ & 179 & 59.4 & 191 & 213 & 179 & 1.30 \\
\hline 7 & Obesity & 45 & $\mathrm{~F}$ & 159 & 92.5 & 81 & 169 & 217 & 2.27 \\
\hline
\end{tabular}

vein or from the right femoral vein and the proper position checked on an $\mathrm{X}$-ray television screen. A slow drip of saline was given through the hepatic vein catheter during the whole study to keep it patent. This procedure took about half an hour from the start of the infusion of Indiocyanine green. With all the catheters in place the subjects then rested comfortably for about 30 minutes before blood sampling was started. Blood
Splanchnic blood flow. The estimated splanchnic plasma flow is given in Fig. 1. During the basal period the average mean flow was $996 \mathrm{ml} / \mathrm{min}$ (range of the mean values $730-1216$ ). This would correspond to an average splanchnic blood flow of about $1650 \mathrm{ml} / \mathrm{min}$. Hultman recently summarized published data on normal values of estimated hepatic blood flow (= splanchnic blood flow) in man and has given an overall 
average figure of $1500 \mathrm{ml} / \mathrm{min}$ in healthy adults [13]. After nicotinic acid there was an initial and transient decrease in three subjects, followed by an increase above the basal flow. The average value for splanchnic plasma flow was $880 \mathrm{ml} / \mathrm{min}(330-1400) 5$ minutes after nicotinic acid and $1106 \mathrm{ml} / \mathrm{min}(560-1770) 30$

\section{EHPF AND NICOTINIC ACID}

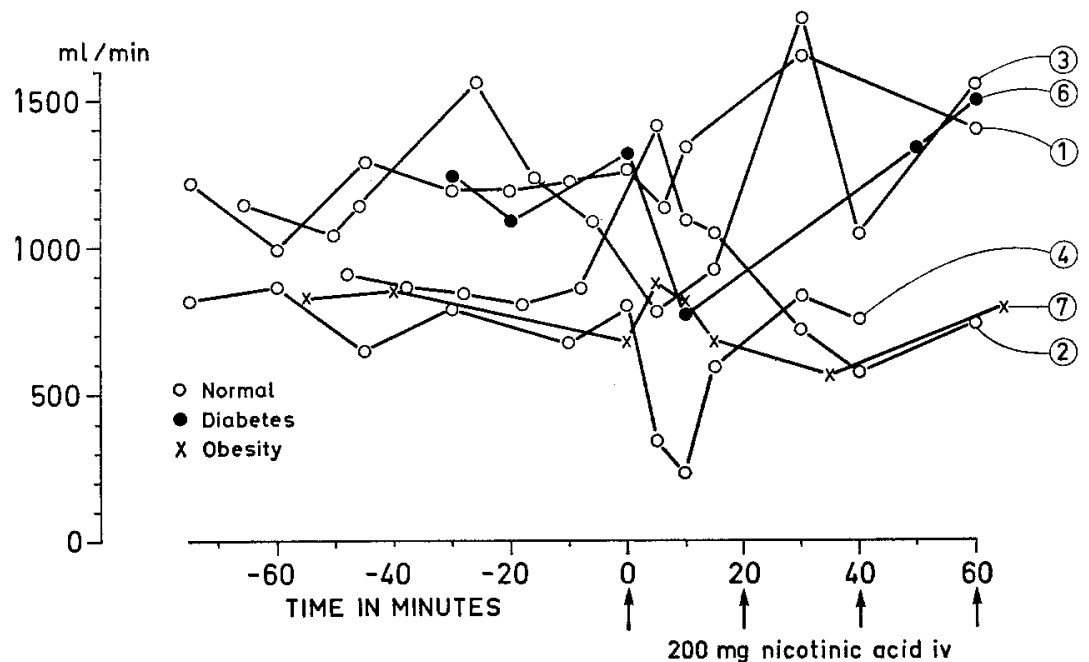

Fig. 1. Estimated splanchnic plasma flow as obtained in 6 of the 7 cases. Case no. is indicated in the figure paration nicotinic acid caused a significant but short decrease in the hepatic blood flow. The decrease seen in man after the intravenous injection of nicotinic acid may thus at least partly be due to a local vaso-constrictor effect of nicotinic acid on hepatic blood vessels.
Plasma free fatty acids. The arterial concentration of FFA is given in Fig. 2. There was a tendency for this concentration to increase slightly during the basal period. Nicotinic acid lowered the FFA level in all cases. The reason for the unusually high FFA level in one of the normal subjects (number 2) is unknown. The normal levels of other plasma lipids and of glucose and the absence of ketonuria suggest that the high levels were probably transitory and not related to any illness.

There was a elose relationship between the arterial FFA level and the arterio-venous difference of FFA over the splanchnic region (Fig. 3) ${ }^{1}$. The general picture indicates that in man the hepatic uptake of FFA is directly proportional to its arterial level. Similar results have been obtained in the $\operatorname{dog}[15,10]$ and in
PLASMA FFA AND NICOTINIC ACID

Arterial levels

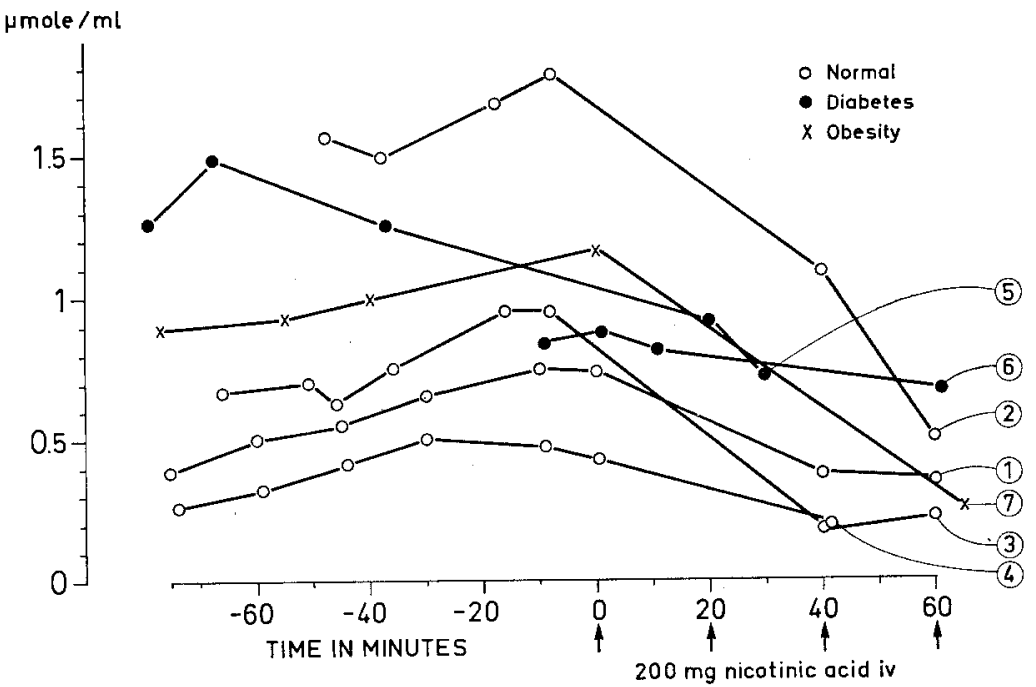

Fig. 2. Arterial concentration of FFA during the study. Case no. is indicated in the figure

minutes after nicotinic acid. The effect of nicotinic acid on splanchnic blood flow has not, to our knowledge, been studied before in man. The initial decrease in flow is consistent with previous findings on the circulation in the isolated, perfused dog liver [5]. In that pre-

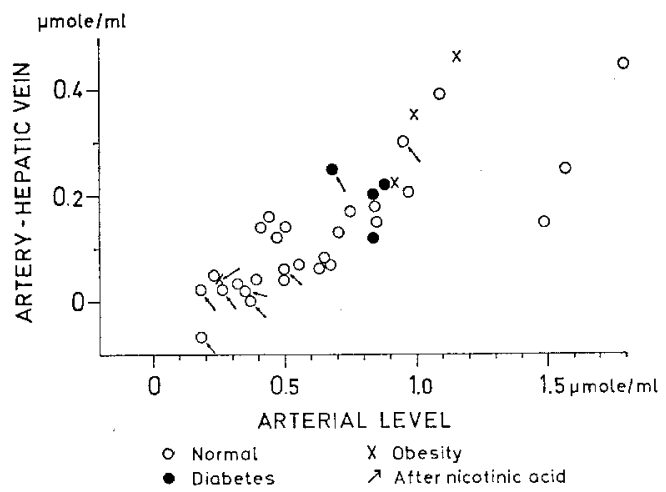

Fig. 3. The concentration difference of FFA between artery and hepatic vein plotted against the arterial FFA level. All values from 6 cases are given

the rat [1] with regard to the liver. The coefficient of correlation for the values in Figure 3 was 0.76 and the equation of the regression line was $y$ $=0.24 x-0.02$. This indicates that the splanchnic region on the average takes up 24 per cent of the FFA being delivered to it.

1 It is noteworthy that subject No. 2 falls somewhat outside this general relation with his three FFA values above $1.5 \mu \mathrm{mole} / \mathrm{ml}$. 
Plasma $\beta$-hydroxybutyric acid. Fig. 4 shows the arterial level of $\beta-\mathrm{HBA}$. This level remained fairly constant during the control period. The administration of nicotinic acid reduced this level in all subjects but one.

\section{PLASMA B-HBA AND NICOTINIC ACID} Arterial levels

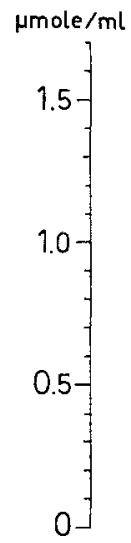

arterial and the hepatic vein plasma for both FFA and $\beta$-HBA. In general the magnitude of the A.V difference of FFA is decreased after nicotinic acid except in one diabetic subject (no reliable hepatic vein FFA values were obtained in the other diabetic patient). The negative $A \cdot V$ difference of $\beta$. HBA was almost completely abolished 60 minutes after nicotinic acid had been given indicating decreased splanchnic production of this ketone body.

The estimated values for splanchnic uptake of FFA and production of $\beta$-HBA are given in Table 2. The average production of $\beta$-HBA during the control period was around 0.2 mmole $/ \mathrm{min}$. Both 40 and 60 minutes after the intravenous administration of nicotinic acid had begun this production was estimated to be, on the average, around $0.01 \mathrm{mmole} / \mathrm{min}$. The production rate of $\beta$-HBA had thus been decreased by about 95 per cent. As $\beta$-HBA is the major ketone body in blood [11] it appears likely that nicotinic acid had depressed total ketone body production.

To see if there was a general relationship between splanchnic $\beta$ HBA production and FFA metabolism, all values for this production were plotted against the simultaneously determined arterial FFA levels (Fig. 7) and splanchnic FFA uptake (Fig. 8). None of these parameters of FFA metabolism appear to be directly related to splanchnic $\beta$-HBA production, at least not in a linear fashion.

\section{Discussion}

This study with its limited number of cases, four normal male subjects, two male diabetic patients and one obese female subject, is not intended to establish any normal or pathological values for the para-

Splanchnic uptake of free fatty acids and production of $\beta$-hydroxybutyric acid. The arterial and hepatic venous levels of FFA and $\beta$-HBA in subject 3 are depicted in Fig. 5. In the control period there was an uptake of FFA and a production of $\beta$-HBA by the splanchnic region. After nicotinic acid the arterial levels of both decreased drastically, and the concentration then remained fairly stable between 40 and 60 minutes. During this period of steady state there was virtually no uptake of FFA and no production of $\beta$-HBA by the splanchnic region. In Figure 6 we have plotted the difference in concentration between the meters studied. However, the effect of nicotinic acid on splanchnic $\beta$-HBA production was so uniform and pronounced in all seven subjects that the purpose of the study - to reveal the immediate cause of the lowering of plasma $\beta$-HBA by nicotinic acid - is well achieved.

The average reduction of splanchnic $\beta$-HBA production by 95 per cent 40 and 60 minutes after nicotinic acid indicates that one major canse of the fall in $\beta$-HBA levels in blood is a reduction of hepatic ketone body formation. It is tempting to believe that this reduction is due to the decreased rate of mobilization of FFA caused by nicotinic acid. It is quite conceivable 
that a reduction in supply of fatty acids from adipose tissue to the liver should decrease the amount of acetate available for ketone body synthesis especially in the fasting state. We could not find, however, any direct, linear relationship between either the arterial still more complex function in which we may have uptake by the liver and other viscera as well as mobilization of FFA from omental adipose tissue. Further careful studies are needed to disclose the possible relationship between FFA metabolism and

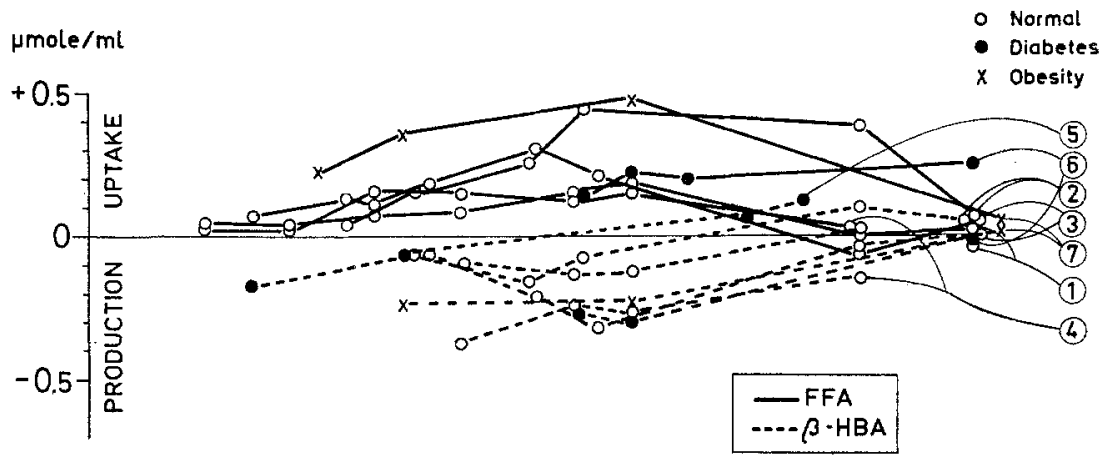

$\begin{array}{cccccc}-60 & -40 & -20 & 0 & 20 & 40 \\ \text { TIME IN MINUTES } & 1 & 1 & 60 \\ 200 \mathrm{mg} \text { nicotinic ocid iv }\end{array}$

Fig. 6. Concentration difference of FFA and of $\beta$-HBA between artery and hepatic vein. Case no. is indicated in the figure

Table 2. Splanchnic uptake of FFA and production of $\beta-H B A$ before and after administration of nicotinic acid. Values in mmole per minute

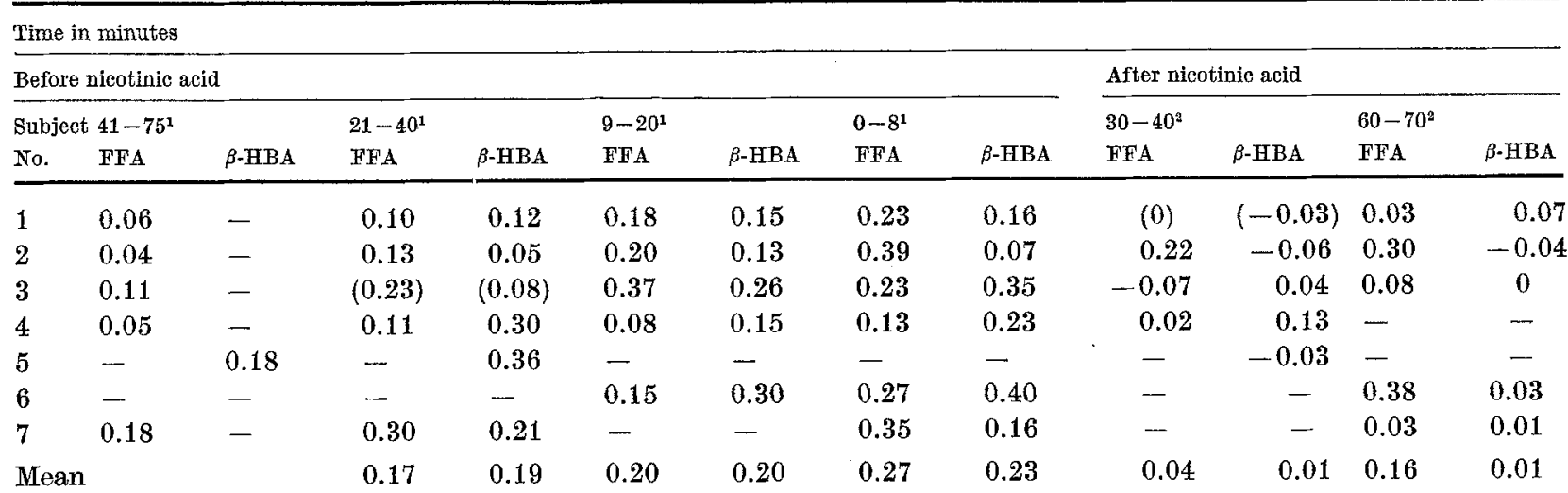

Values calculated by multiplying estimated hepatic plasma flow by the concentration difference between arterial and hepatic venous plasma. Figures within brackets calculated from interpolated values of estimated hepatic plasma flow.

1 Time (minutes) before nicotinic acid.

2 Time (minutes) after first injection of nicotinic acid.

level of FFA or the splanchnic uptake of FFA and the estimated ketone body production. Many facts make it difficult to draw definite conclusions from this lack of correlation. For instance, the estimated. splanchnic production of $\beta$-HBA has at least two different components, the hepatic production of $\beta$ HBA and the uptake of $\beta$-HBA by other splanchnic viscera. The estimated splanchnic uptake of FFA is a the production of ketone bodies. As the FFA level in arterial blood fell in all cases it is possible that the production of the ketone bodies may be related to changes and not to absolute values of FFA mobilization. It is of course also possible that nicotinic acid has a direct effect in the liver on the formation of $\beta$-HBA not related to the effect on FFA metabolism. However, it has recently been found that agents other than 
nicotinic acid which inhibit FFA mobilization, also lower the levels of $\beta$-HBA in plasma of rats $[2,3]$. This suggests that it is indeed the effect on FFA mobilization that causes the lowering of the production of $\beta$-HBA.

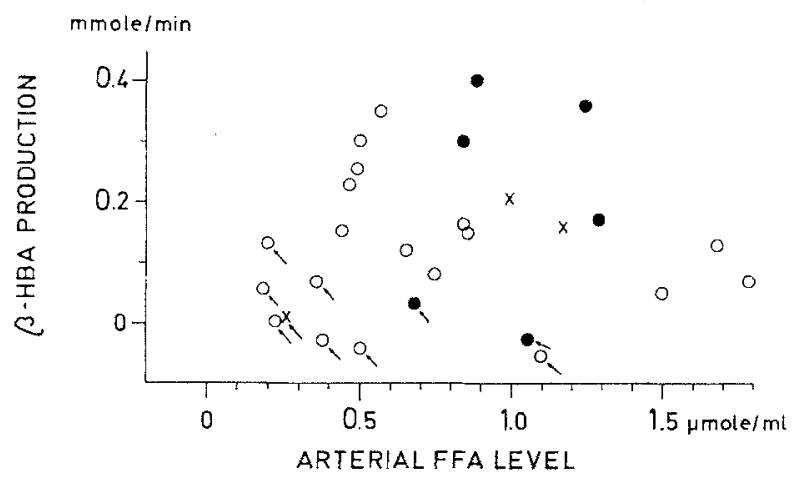

Fig. 7. Splanchnic production of $\beta$-HBA and arterial concentration of FFA. Arrows indicate values obtained after nicotinic acid

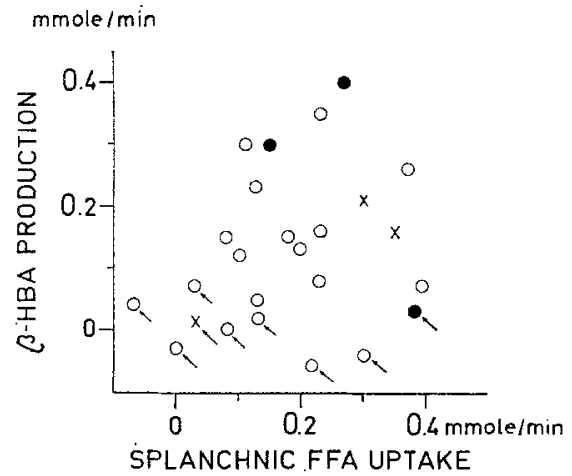

Fig. 8. Splanchnic production of $\beta$-HBA and splanchnic uptake of FFA. Arrows indicate values obtained after nicotinic acid

\section{References}

[1] Aydin, A., and J.E. Sokal: Uptake of plasma free fatty acids by the isolated rat liver: effect of glucagon. Amer. J. Physiol. 205, 667-670 (1963).

[2] Brzzi, A., M.T. Tacconi and S. Garatimn : Lowering of blood ketone bodies induced by drugs preventing free fatty acid mobilization. Experientia 22, 664 (1966).

[3] Bubenheimer, P., A. Hasselblatt and U. Schwa. BE: Hemmung der Ketonämie bei Hunger und Insulinmangel durch 3,5-Dimethylisoxazol. Klin. Wschr. 44, 713 - 716 (1966).

[4] Carlson, L.A.: Inhibition of the mobilization of free fatty acids from adipose tissue. Ann. N.Y. Acad. Sci, 131, 119-142 (1965).
[5] - Consequences of inhibition of normal and excessive lipid mobilization. Studies with nicotinic acid. In Progr. biochem. Pharmacol. Vol. 3. Basel/New York, Karger, p. 151-166, 1967

[6] -, J. Boberg and B. Högstedt: Some physiological and clinical implications of lipid mobilization from adipose tissue. In Handbook of Physiology V. Adipose Tissue. Washington, Amer. Physiol. Soc., p. $625-644,1965$.

[7] -, and L. ORö: The effect of nicotinic acid on the plasma free fatty acids. Demonstration of a metabolic type of sympathicolysis. Acta med. scand. 172, $641-645$ (1962).

[8] - and J. ÖsTMAN: Plasma $\beta$-hydroxybutyric acid response to nicotinic acid-induced plasma free fatty acid decrease in man. Diabetologia 2, 127-129 (1966).

[9] Dous, V.P.: A relation between nonesterified fatty acids in plasma and the metabolism of glucose. $J$. clin. Invest. 35: $150-154$ (1956).

[10] Frne, M.B., and R.H. WrLliams: Effect of fasting, epinephrine and glucose and insulin on hepatic uptake of nonesterified fatty acids. Amer. J. Physiol. 199, $403-406(1960)$.

[11] GAMMELFOFT, A.: Ratio of $\beta$-hydroxybutyric acid to acetoacetic acid in the blood under various experimental conditions. Acta physiol. scand. 24, 35-48 (1951).

[12] Garland, P.B., E.A. Newsholme and P.J. Randle: Regulation of glucose uptake by muscle. 9. Effects of fatty acids and ketone bodies, and of alloxan-diabetes and starvation, on pyruvate metabolism and on lactate/pyruvate and L-glycerol 3-phosphate/ dihydroxyacetone phosphate concentration ratios in rat heart and rat diaphragm muscles. Biochem. J. $93,665-678$ (1964).

[13] Hultman, E.: Blood circulation in the liver under physiological and pathological conditions. Scand. J. clin. Lab. Invest. 18, Suppl. 92, p. 27-41 (1966).

[14] Shipp, J.C., L.H. Opie and D. Challoner: Fatty acid and glucose metabolism in the perfused rat heart. Nature 189, 1018-1019 (1961).

[15] SpITzer, J.J., and W.T. Mc Elroy, Jr.: Some hormonal effects on uptake of free fatty acids by the liver. Amer. J. Physiol. 199, 876-878 (1960).

[16] Trout, D.L., E.H. Estes and S.J. Fruedberg: Titration of free fatty acids of plasma: a study of current methods and a new modification. J. Lipid Res. 1, $199-202$ (1960).

[17] WILLIAmson, J.R., and H.A. KREBS: Acetoacetate as fuel of respiration in the perfused rat heart. Biochem. J. 80, 540-548 (1961).

[18] Williamson, D.H., J. Mellanby and H.A. Krebs: Enzymic determination of $\mathrm{D}(-)-\beta$-hydroxybutyric acid and acetoacetic acid in blood. Biochem. J. 82, $90-96$ (1962).

[19] WINkLER, K., and N. Tygstrup: Determination of hepatic blood flow in man by Cardio Green. Scand. J. clin. Lab. Invest. 12, 353-356 (1960).

Lars A. Carison, M.D.

King Gustaf Vth Research Institute Stockholm 60, Sweden 